\title{
Identification of skate nursery habitat in the eastern Bering Sea
}

\author{
Gerald R. Hoff* \\ NOAA, National Marine Fisheries Service, Alaska Fisheries Science Center, 7600 Sand Point Way NE, Seattle, \\ Washington 98115, USA
}

\begin{abstract}
Identification of habitat used for skate egg deposition has been rarely studied or reported worldwide. Four nursery sites for the Alaska skate Bathyraja parmifera, 2 for the Aleutian skate $B$. aleutica and 2 for the Bering skate $B$. interrupta were identified along the upper continental slope in the eastern Bering Sea. All sites were located near undersea canyons from 145 to $380 \mathrm{~m}$ depth in relatively flat sandy to muddy bottom habitat. Bottom temperatures were relatively constant throughout the year, varying from 3.7 to $4.6^{\circ} \mathrm{C}$. Egg case densities varied between nursery sites and were encountered at the Alaska skate nursery in Bering Canyon at densities greater than 800000 eggs $\mathrm{km}^{-2}$. Based on egg case composition, sites were predominantly used by a single skate species for egg deposition; however, up to 6 skate species used the habitat commonly. Seasonal sampling indicated that sites were continuously occupied throughout the year, and embryo length composition showed multiple cohorts developing simultaneously. Data from bottom trawl surveys suggest juvenile skates occupy habitats different than nursery sites. The movement of juvenile skates out of nursery habitat after hatching may lessen predation by common predators such as the Pacific cod Gadus macrocephalus and the Pacific halibut Hippoglossus stenolepis.
\end{abstract}

KEY WORDS: Elasmobranch $\cdot$ Skate $\cdot$ Reproduction $\cdot$ Egg case $\cdot$ Undersea canyon $\cdot$ Nursery $\cdot$ Alaska Resale or republication not permitted without written consent of the publisher

\section{INTRODUCTION}

Characterization of habitat used for reproduction and early life stages of oviparous elasmobranchs (i.e. skates, family Rajidae) is virtually unknown, with few studies reported (Hoff 2007, 2008, Love et al. 2008). Identification of nursery habitat for egg deposition may be limited by small size making them difficult to locate, by association with high relief areas (i.e. rocky) that are difficult to sample or by occurrence in deeper waters of the continental slope that are often undersampled (Hitz 1964, Hoff 2007, 2008, Love et al. 2008).

Nursery sites for viviparous elasmobranchs (sharks) are known (Castro 1993, Carlson 1999, Feldheim et al. 2002, Yokota \& Lessa 2006) and habitat requirements have been identified for many species. Shark nursery sites may be ephemeral and/or seasonal, and neonates can reside for extended periods using the sites for protection and as an optimal food resource. In contrast, recent findings suggest skate nursery sites remain in use throughout the year, and newly emergent skates exit sites soon after hatching, occupying areas at depths different than those of egg deposition (Hoff 2007, 2008, Love et al. 2008). There appear to be fundamental differences in the nursery habitat use between oviparous and viviparous elasmobranch species, suggesting that habitat identification may be critical for successful management and conservation of these little known fishes (Packer et al. 2003).

In the eastern Bering Sea (EBS) 12 skate species are recognized, with only 3 species comprising the bulk of the skate biomass and populations (Hoff \& Britt 2003, 2005, 2009, Lauth \& Acuna 2009). The Alaska skate Bathyraja parmifera dominates the continental shelf environment $(20$ to $200 \mathrm{~m}$ ) and the Aleutian skate $B$. aleutica and the Bering skate $B$. interrupta are the dominant skate species along the EBS slope (200 to 1200 m) (Hoff \& Britt 2005, 2009, Stevenson et al. 2008, 
Lauth \& Acuna 2009). Combined these 3 species constitute $>95 \%$ of the skate population and biomass in the entire EBS (20 to $1200 \mathrm{~m}$ depth) and are the major components of skate bycatch in non-target commercial bottom trawl and longline fisheries (Stevenson 2004). Other important slope-dwelling species in the EBS include the whiteblotched skate $B$. maculata, the mud skate $B$. taranetzi, the Commander skate $B$. lindbergi and the whitebrow skate B. minispinosa (Hoff \& Britt 2009).
This study focuses on identification of skate nursery habitat for 3 abundant skate species in the eastern Bering Sea. Four nursery sites for the Alaska skate, 2 nursery sites for the Aleutian skate, and 2 nursery sites for the Bering skate (Fig. 1) are described. Some important biological aspects examined were skate and skate egg case composition, egg case densities and predation on juvenile skates. Nursery habitat parameters include location, temporal use, depth, temperature, bottom topography and associated sessile fauna

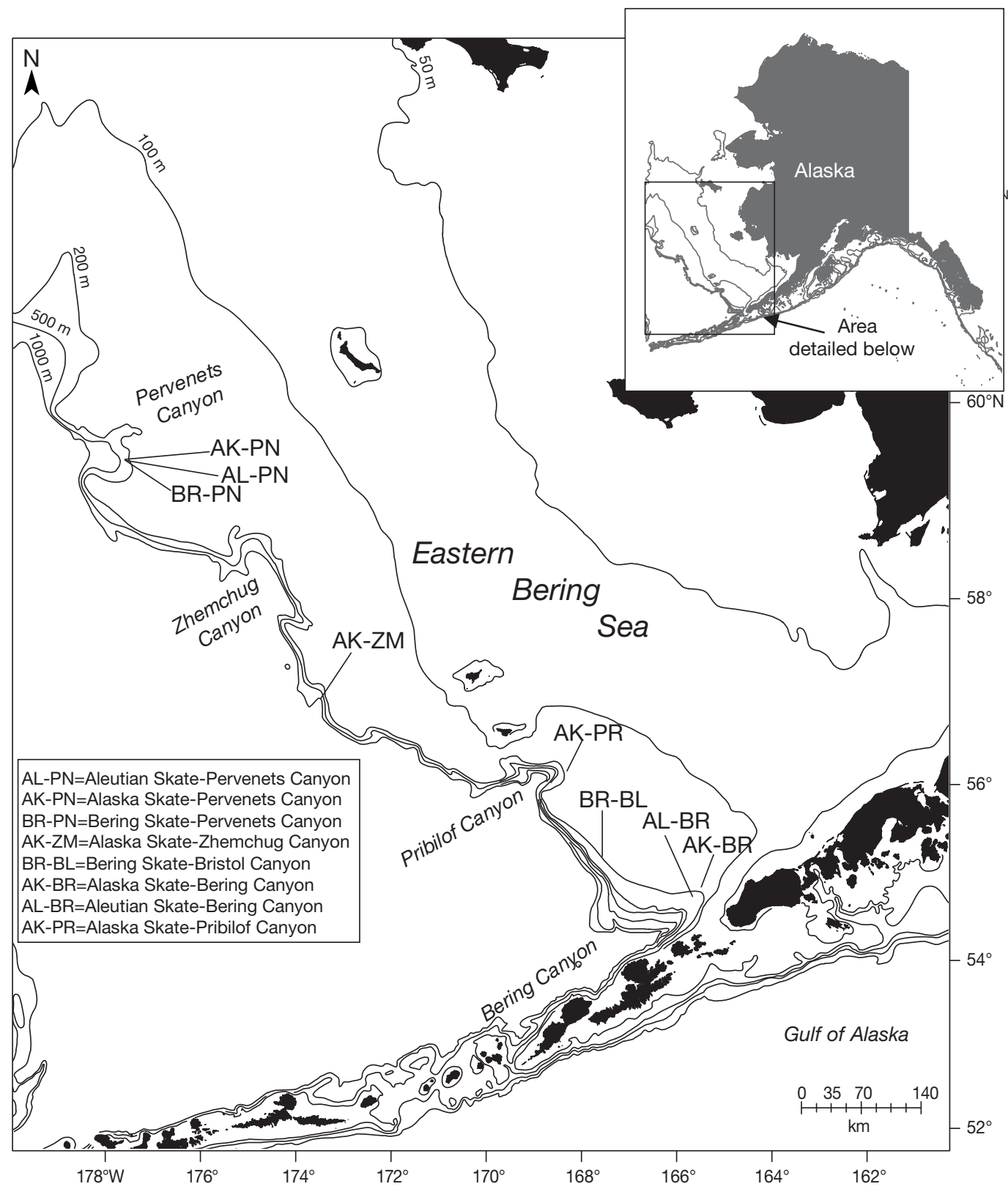

Fig. 1. Location of 8 skate nursery sites in the eastern Bering Sea and their species-canyon location designations. The AK-PR site has not been studied in detailed and is included to document its location in Pribilof Canyon. Inset shows general location of the study area in the Bering Sea 
that may assist in identification of habitat used for reproduction.

\section{MATERIALS AND METHODS}

Nursery habitat identification. Initial locations of nursery sites were identified based on fisheries data, and previous survey trawls in which large numbers of skate egg cases were reported in the catch. Identified sites were subsequently sampled using bottom trawls in an adaptive sampling approach to identify the egg case distribution and estimate the size of the habitat used for egg deposition. At each site trawls were conducted in each of 4 directions (north, south, east, west) at approximately 0.5 to $1.0 \mathrm{~km}$ start distance from the previous trawl. Trawling proceeded in a single direction until total egg case counts within a haul consistently lessened. During trawling it was found that due to the 'stickiness' of egg cases in the trawl webbing it could not be determined whether eggs encountered were new or from a previous trawl; therefore, a reduced egg case density of $<1000$ eggs $\mathrm{km}^{-2}$ (ca. 10 to 15 eggs trawl ${ }^{-1}$ ) was used as a stopping criteria and indicated the end of the egg case distribution or a reduction to non-detectable limits by the trawl. In sites where seasonal sampling occurred, additional trawls were conducted in the high density areas. Each site was sampled a varying number of times and seasons between 2004 and 2008 and data presented are from all sampling periods (Table 1). The ship's echosounder (Es60) input was used to identify any unique relief, sediment type and hardness during trawling operations.

Bottom trawl sampling methods. Trawl samples conducted at skate nursery sites and those of Alaska Fisheries Science Center (AFSC) survey trawls on the EBS shelf (0 to $200 \mathrm{~m}$ depth) used similar trawling methods (for details see Stauffer 2004, Lauth \& Acuna 2009). The trawl used was an 83-112 eastern otter trawl with a $25.3 \mathrm{~m}$ headrope and $34.1 \mathrm{~m}$ footrope that consisted of a single firehose-wrapped chain lacking any bobbins or discs, and $32 \mathrm{~mm}$ stretched-mesh liner in the cod end. At egg deposition sites, towing time was shortened from a standard $30 \mathrm{~min}$ trawl to between 5 and 10 min due to the large biomass and uncertainty of location with long tow distances. During each tow, starting and ending latitude, longitude and bottom depth were recorded; net width was recorded using acoustic trawl mensuration gear, and bottom temperatures were recorded using a Seabird micro-bathythermograph data recorder attached to the net. The swept area was estimated from average net width and distance fished during each trawl. Data for skate and egg depth and temperature distribution were collected from the annual EBS shelf survey (8 to $200 \mathrm{~m}$ ) and the biennial EBS slope survey (200 to $1200 \mathrm{~m}$ ) using AFSC standardized methods (for details see Stauffer 2004, Hoff \& Britt 2009, Lauth \& Acuna 2009). The slope trawl used was a Poly Nor'eastern net with a $27.2 \mathrm{~m}$ headrope and $24.9 \mathrm{~m}$ footrope consisting of mudsweep roller gear and $32 \mathrm{~mm}$ stretched-mesh line in the cod end.

Biological data at nursery sites. Fishes, invertebrates and skate egg cases were identified, weighed and enumerated during each sampling period. Egg cases were further sorted and counted into those possessing a developing embryo (full) or those which were post-hatch or otherwise void of an embryo or contents (empty). Density estimates (catch per unit effort $\left[\right.$ CPUE] $=$ no. skates $\mathrm{km}^{-2}$ or no. egg cases $\mathrm{km}^{-2}$ ) were calculated as the number of individuals in each trawl divided by the trawl area swept. The percentage of full eggs was calculated as the number of full eggs divided by the total egg counts by species in each haul. Stomach contents from selected predatory species and skates were examined during all sampling periods at nursery sites. Fish weights were recorded to the nearest $0.1 \mathrm{~g}$ and lengths to the near-

Table 1. Skate nesting sites of the eastern Bering Sea; their egg density characteristics and bottom temperature. Temperatures in bold text represent the month and bottom temperature where maximum egg case densities and percent developing eggs were sampled

\begin{tabular}{|c|c|c|c|c|c|c|c|c|c|c|c|c|}
\hline $\begin{array}{l}\text { Nursery site } \\
\text { designation }\end{array}$ & $\begin{array}{l}\text { Depth of } \\
\text { maximum } \\
\text { egg case } \\
\text { density }(m)\end{array}$ & $\overline{\mathrm{Jan}}$ & Apr & $\begin{array}{l}\text { - Bottc } \\
\text { May }\end{array}$ & $\begin{array}{l}\text { Jun te } \\
\text { Jun }\end{array}$ & $\begin{array}{l}\text { mperc } \\
\text { Jul }\end{array}$ & $\begin{array}{r}\text { ature } \\
\text { Aug }\end{array}$ & $\begin{array}{l}\left({ }^{\circ} \mathrm{C}\right) \\
\text { Sep }\end{array}$ & Oct & Nov & $\begin{array}{c}\text { Maximum } \\
\text { egg density } \\
(\text { no. eggs } \\
\left.\mathrm{km}^{-2}\right)\end{array}$ & $\begin{array}{c}\text { Eggs } \\
\text { with } \\
\text { embryos } \\
(\%)\end{array}$ \\
\hline Alaska skate-Pervenets Canyon (AK-PN) & 316 & & & & & & 3.9 & & & & 334163 & 62.6 \\
\hline Alaska skate-Zhemchug Canyon (AK-ZM) & 217 & & & & & 3.9 & & & & & 610064 & 80.2 \\
\hline Alaska skate-Pribilof Canyon (AK-PR) & 205 & & & 3.8 & 3.8 & & 4.0 & & & & 16473 & \\
\hline Alaska skate-Bering Canyon (AK-BR) & 145 & 4.3 & 4.1 & & 4.2 & 4.5 & 4.5 & & 4.4 & 4.6 & 800406 & 40.9 \\
\hline Aleutian skate-Pervenets Canyon (AL-PN) & 320 & & & & & & 3.9 & & 3.8 & & 81927 & 68.0 \\
\hline Aleutian skate-Bering Canyon (AL-BR) & 380 & 4.3 & 4.0 & & & 3.9 & 4.0 & 3.8 & 3.7 & 4.0 & 62992 & 86.7 \\
\hline Bering skate-Pervenets Canyon (BR-PN) & 337 & & & & & & 3.9 & & 3.8 & & 49567 & 33.0 \\
\hline Bering skate-Bristol Canyon (BR-BL) & 156 & & & & & 4.2 & & & & & 6188 & 56.0 \\
\hline
\end{tabular}


est $1.0 \mathrm{~cm}$. Stomach contents were sorted into prey categories and identified to the lowest possible taxa, enumerated and weighed. The presence and abundance of juvenile skates in the stomach was recorded. A random sample of full skate egg cases chosen for embryo measurements was preserved in either $10 \%$ formalin or $95 \%$ ethanol from each egg deposition site. Embryos were removed from egg cases and total lengths (TL including tail filaments, $\mathrm{mm}$ ) were measured. Eggs containing embryos of approximately $<15 \mathrm{~mm}$ were considered in stage 1 and not routinely measured due to the difficulty of identification and measurement of the embryo.

Historical skate and egg case data from AFSC surveys. The depth distribution at size (length) for the 7 most abundant skate species was obtained from the AFSC's EBS shelf and slope groundfish surveys conducted simultaneously in 2000, 2002, 2004 and 2008 for the slope species, and from 2000 to 2008 for the Alaska skate. Data for each species irrespective of sex was pooled for all survey years and an estimated mean depth $(\mathrm{m})$ and SE of the depth estimated for each length unit (cm TL).

Encounters of skate eggs from survey trawls conducted in the EBS was obtained from the AFSC's groundfish trawl database using all EBS bottom trawl survey data from 1982 to 2009 for depths 8 to $1200 \mathrm{~m}$. Data were pooled for all survey years and a density estimate $\left(\right.$ mean CPUE $=$ no. eggs $\mathrm{km}^{-2}$ ) was calculated as the total number of skate eggs encountered at a $25 \mathrm{~m}$ depth interval divided by the total area swept by all survey trawls completed in that depth interval. An alternative density estimate (mean CPUE $=$ no. of eggs $\mathrm{km}^{-2}$ ) was estimated for bottom temperature as the total number of skates eggs encountered at each $0.1^{\circ} \mathrm{C}$ bottom temperature interval divided by the total area swept by all survey trawls conducted at that temperature.

\section{RESULTS}

\section{Nursery habitat}

Each site was given a designation based on the predominant species of skate egg cases present and the marine canyon associated with the site (Fig. 1). Designations were: Alaska skate-Pervenets Canyon (AKPN), Alaska skate-Zhemchug Canyon (AK-ZM), Alaska skate-Pribilof Canyon (AK-PR), Alaska skateBering Canyon (AK-BR), Aleutian skate-Pervenets Canyon (AL-PN), Aleutian skate-Bering Canyon (AL$\mathrm{BR})$, Bering skate-Pervenets Canyon (BR-PN), and Bering skate-Bristol Canyon (BR-BL).

The AK-BR site was sampled most frequently with a total of 29 trawls and sampling completed in nearly all months of the year. The AK-PN site was the least frequently sampled known from only a single trawl conducted during August of 2006. The AK-PR site has not been mapped and is known from a past AFSC survey trawl (1979), which encountered an egg density of $>16000$ eggs $\mathrm{km}^{-2}$. There are numerous reports in National Marine Fisheries Service (NMFS) fishery data for this location, and a 2008 AFSC survey trawl conducted near the site encountered many empty skate egg cases, which suggests a possible large nursery site in the vicinity (Hoff \& Britt 2009).

In general skate nursery sites possessed areas of high numbers of viable eggs (>30\%) surrounded by broadly scattered areas of predominantly (>70\%) empty egg cases (Fig. 2). Egg cases were encountered lying directly on the seafloor on flat sandy to muddy bottom and were found over a narrow depth range of the upper slope and outer shelf from 145 to $380 \mathrm{~m}$. Sites were commonly associated with canyon heads with 3 in Pervenets Canyon, 1 south of Zhemchug Canyon, 1 in Pribilof Canyon, 2 associated with Bering Canyon, and 1 in Bristol Canyon. Depths varied little within individual sites with the highest concentrations of eggs often occurring over $<20$ m depth range. Composition of sessile attached invertebrates provided little evidence of substrates or distinct species associations that could be used to identify site habitat. Sponges ( 0.4 to $1457.03 \mathrm{~kg} \mathrm{~km}^{-2}$ ), sea whips (0.4 to $294.10 \mathrm{~kg} \mathrm{~km} \mathrm{~km}^{-2}$ ) and polychaete worm tubes ( 0.16 to $165.43 \mathrm{~kg} \mathrm{~km} \mathrm{~km}^{-2}$ ) were among the 3 most common sessile invertebrates encountered and all were in relatively low densities. Bottom temperatures for all sites and sampling times ranged from 3.7 to $4.6^{\circ} \mathrm{C}$ (Table 1). The most complete seasonal sampling conducted at the AK-BR site showed bottom temperatures varied by only $0.5^{\circ} \mathrm{C}$ throughout the year.

\section{Biological data at nursery sites}

Maximum egg case densities varied dramatically between sites and among the 3 species (Table 1). Alaska skate nursery sites had the highest egg case densities with the highest at the AK-BR site, while the Aleutian skate and Bering skate nursery sites had 1 and, at the BR-BL site, even 2 orders of magnitude lower egg densities. Both the Aleutian and Bering skate sites displayed trends opposite those of the Alaska skate site by having higher egg case densities at northern sites than at southern sites (Fig. 2). Nursery sites possessed up to $86 \%$ eggs containing developing embryos (full eggs), and in general egg case densities were higher for the Alaska and Bering skate sites during June to August sampling, and during the October 

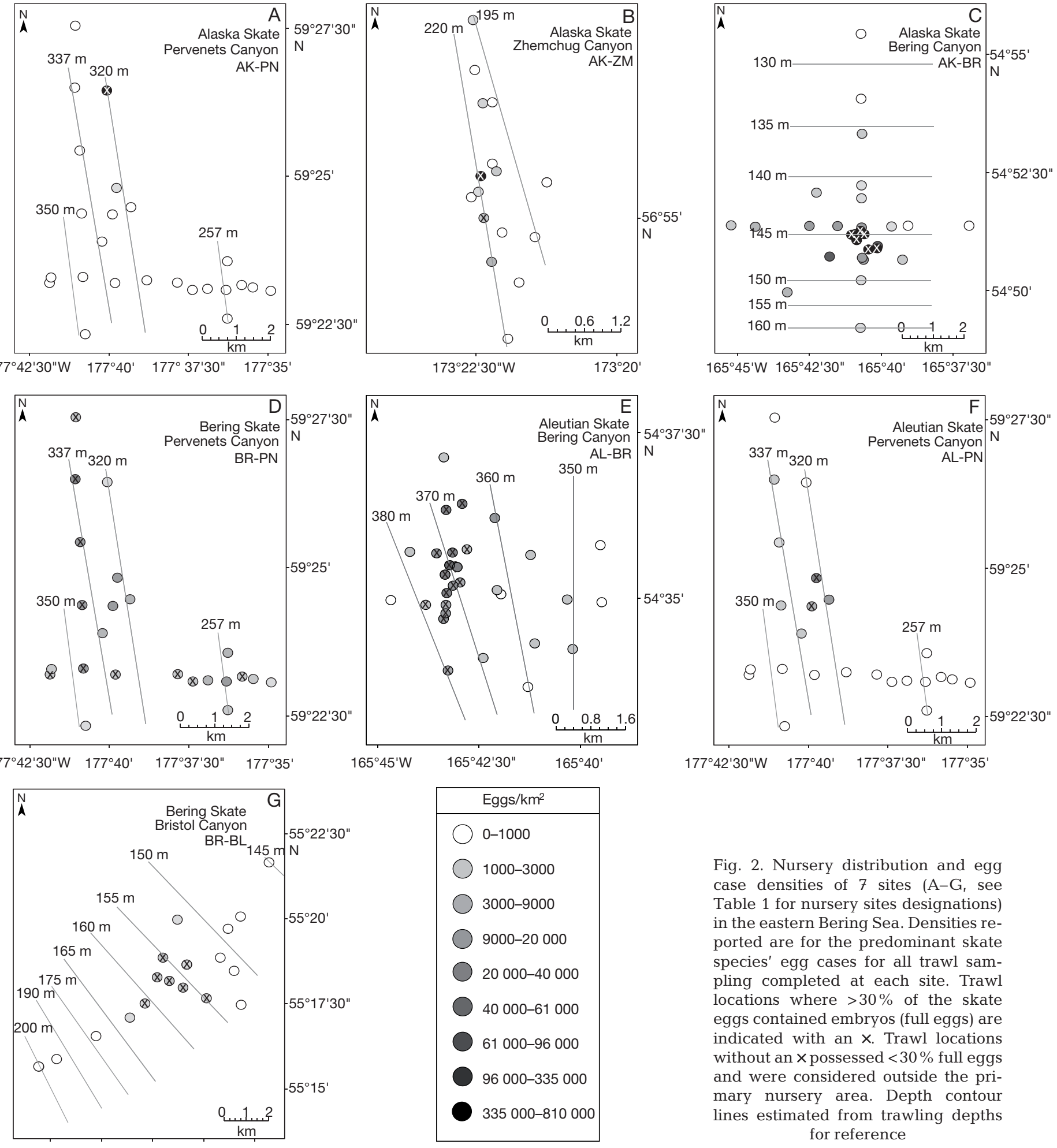

$167^{\circ} 42^{\prime} 30^{\prime \prime} \mathrm{W}$

$167^{\circ} 37^{\prime} 30^{\prime \prime}$

$167^{\circ} 32^{\prime} 30^{\prime \prime}$

to January sampling for the Aleutian skate site, although complete seasonal sampling is lacking at all sites throughout the year to evaluate the trends thoroughly.
Species diversity of adult or juvenile skates was often high at nursery sites while species diversity of egg cases was low. Nursery sites had egg cases from 3 to 6 skate species; however, egg case composition
Fig. 2. Nursery distribution and egg case densities of 7 sites (A-G, see Table 1 for nursery sites designations) in the eastern Bering Sea. Densities reported are for the predominant skate species' egg cases for all trawl sampling completed at each site. Trawl locations where $>30 \%$ of the skate eggs contained embryos (full eggs) are indicated with an $x$. Trawl locations without an $\times$ possessed $<30 \%$ full eggs and were considered outside the primary nursery area. Depth contour lines estimated from trawling depths for reference 
reflected a predominance of a single skate species' eggs at each site (Fig. 3). An exception to this was the AL-PN site, where the Bering skate eggs comprised nearly $40 \%$ of the egg case composition. In general, the Bering skate appeared to deposit eggs across a much broader area and at lower densites than the Alaska or Aleutian skates. Encounters of post-hatch and adult skates showed the Alaska skate as the dominant species at the Alaska skate sites and the BR-BL site, and less common at other sites. Aleutian skate sites (AL-PN and AL-BR) and the Bering skate site BRPN were dominated by the immature and adult stages of the mud skate; other skates such as the whiteblotched skate, Aleutian skate, Bering skate and Alaska skate were also in abundance at these sites.

Pacific cod Gadus macrocephalus, Pacific halibut Hippoglossus stenolepis, Aleutian skate and whiteblotched skate all consumed newly emergent skates at nursery sites (Table 2). In general, the predation level (number of prey per number of fish examined) estimated from sites $(29.07 \%$, Table 2$)$ in the present study was several orders of magnitude higher than predation levels estimated for Pacific halibut and Pacific cod collected from widely scattered samples from a seasonal survey conducted throughout the EBS shelf and slope (0.07\%, AFSC Feeding Ecology Lab unpubl. data).
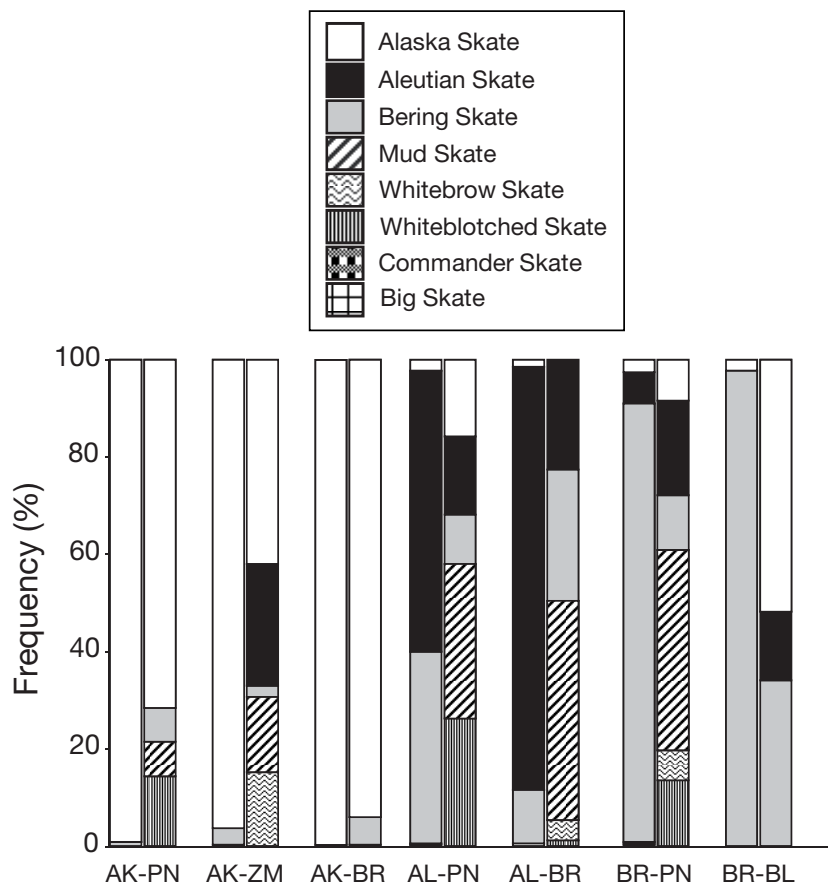

Fig. 3. Species composition of skate egg cases (left bar of each pair) and juvenile and adult skates (right bar of each pair) for each nursery for all trawls combined conducted at that site. Each set of bars represents a comparison between the egg case composition and the post-emergent skates encountered at the individual nursery site. See Table 1 for nursery site designations
Most consumed skate specimens at nursery sites were partially to entirely digested, which limited positive identification; however, based on size, all skates consumed appeared to be neonates of the Alaska or Bering skates.

Embryo length composition from 5 nursery sites showed that developing embryos spanned a wide size range, some with multiple cohorts (Fig. 4). Most sites possessed eggs that were recently deposited (stage $1=$ little development) and in early stages of embryo development $(<40 \mathrm{~mm})$, and those near hatching size (approximately $250 \mathrm{~mm}$ for the Aleutian and Alaska skates, $160 \mathrm{~mm}$ for the Bering skate) (for description of embryo stages see Hoff 2008, 2009a).

\section{Historical skate and egg case data}

Historical survey data showed consistent patterns of ontogenetic shifts in habitat for the 7 EBS slope skate species examined. The Alaska skate juveniles used the inner and middle shelf with nursery sites and adults primarily found along the outer shelf and slope (Fig. 5A; Hoff 2008). Likewise, the Aleutian and Bering skates nursery sites and adults were found along the outer shelf and slope edge while juvniles used deep slope habitat (Fig. 5B-G). General ontogenetic movement and habitat use of other slope-dwelling skate species, such as the whiteblotched skate, mud skate, Commander skate and whitebrow skate, were all similar to those of the Aleutian and Bering skates (Fig. 5C-G).

Data summarized from 28 yr (from 1982 to 2009, $>14000$ trawls) of AFSC survey bottom trawls indicate that skate nursery sites are primarily an outer shelf to upper slope phenomenon. AFSC survey trawls were conducted between 8 and $1200 \mathrm{~m}$ depths across the EBS shelf and upper slope region and the distribution of skate egg cases indicated that $92 \%$ of all egg cases were encountered between 125 and 400 m depths (Fig. 6). Bottom temperatures from AFSC surveys ranged from -2.1 to $13.7^{\circ} \mathrm{C}$ with $90 \%$ of skate egg cases occurring at bottom temperatures from 3.0 to $5.0^{\circ} \mathrm{C}$ (Fig. 6).

\section{DISCUSSION}

Skate nursery habitats identified in the present study appear closely tied to the outer shelf and upper slope canyon areas, particularly canyon heads, in the EBS. The EBS possesses some of the largest undersea canyons in the world (Carlson \& Karl 1988), which stretch across the shelf-slope interface from the international dateline to Unimak Pass. Unique habitats can be formed at the heads of canyons due to currents 
Table 2. Predator species examined at each skate nursery site. Frequency of occurrence (number of individual predators with skates as prey items) and the number of skates consumed combined for each site and predator species. Predominant prey is by weight from entire stomach contents. -: no prey, empty stomach

\begin{tabular}{|c|c|c|c|c|c|}
\hline $\begin{array}{l}\text { Nursery site designation } \\
\text { Species }\end{array}$ & $\mathrm{n}$ & $\begin{array}{l}\text { Predator } \\
\text { size range } \\
\quad(\mathrm{cm})\end{array}$ & $\begin{array}{l}\text { Frequency } \\
\text { of } \\
\text { occurrence }\end{array}$ & $\begin{array}{c}\text { Total } \\
\text { skates } \\
\text { as prey }\end{array}$ & Predominant prey \\
\hline \multicolumn{6}{|l|}{ Alaska skate-Pervenets Canyon (AK-PN) } \\
\hline Pacific cod & 4 & $55-74$ & 2 & 5 & Skate, shrimp \\
\hline Pacific halibut & 1 & 82 & 0 & 0 & Octopus \\
\hline \multicolumn{6}{|l|}{ Alaska skate-Zhemchug Canyon (AK-ZM) } \\
\hline Arrowtooth flounder & 73 & $31-71$ & 0 & 0 & Fish, shrimp \\
\hline Pacific cod & 24 & $56-90$ & 9 & 35 & Pollock, shrimp, crab \\
\hline Pacific halibut & 3 & $80-141$ & 0 & 0 & Pacific cod, cephalopod \\
\hline Bigmouth sculpin Hemitripterus bolini & 5 & $53-63$ & 0 & 0 & Fish \\
\hline Bering skate & 1 & 80 & 0 & 0 & Amphipod \\
\hline Alaska skate & 24 & $94-107$ & 0 & 0 & Pollock, fish, shrimp, crab \\
\hline Aleutian skate & 16 & $83-132$ & 1 & 1 & Fish, shrimp \\
\hline Whitebrow skate & 9 & $71-80$ & 0 & 0 & Shrimp \\
\hline Mud skate & 9 & $61-71$ & 0 & 0 & Amphipod, shrimp \\
\hline \multicolumn{6}{|l|}{ Alaska skate-Bering Canyon (AK-BR) } \\
\hline Arrowtooth flounder & 140 & $20-81$ & 0 & 0 & Euphausid shrimp, pollock \\
\hline Pacific cod & 170 & $35-102$ & 5 & 10 & Crab, pollock \\
\hline Pacific halibut & 63 & $33-92$ & 9 & 30 & Crab, pollock \\
\hline $\begin{array}{l}\text { Great sculpin Myoxocephalus } \\
\text { polyacanthocephalus }\end{array}$ & 3 & $47-63$ & 0 & 0 & Pollock, tanner crab \\
\hline Greenland turbot & 1 & 83 & 0 & 0 & - \\
\hline Bering skate & 36 & $55-82$ & 0 & 0 & Euphasid shrimp \\
\hline Alaska skate & 178 & $62-115$ & 0 & 0 & Pollock \\
\hline \multicolumn{6}{|l|}{ Aleutian skate-Pervenets Canyon (AL-PN) } \\
\hline Whiteblotched skate & 1 & 101 & 0 & 0 & Cephalopod \\
\hline Mud skate & 2 & $36-47$ & 0 & 0 & Gamarid, polychaete \\
\hline Greenland turbot & 5 & $66-68$ & 0 & 0 & - \\
\hline Bigmouth sculpin & 1 & 58 & 0 & 0 & - \\
\hline \multicolumn{6}{|l|}{ Aleutian skate-Bering Canyon (AL-BR) } \\
\hline Arrowtooth flounder & 150 & $34-67$ & 0 & 0 & Cephalopods, myctophids \\
\hline Pacific cod & 4 & $48-65$ & 0 & 0 & Shrimp \\
\hline Pacific halibut & 33 & $39-82$ & 0 & 0 & Crab, pollock \\
\hline Sablefish Anoplopoma fimbria & 9 & $45-62$ & 0 & 0 & Fish \\
\hline Bigmouth sculpin & 8 & $43-68$ & 0 & 0 & Pollock \\
\hline Greenland turbot & 67 & $60-91$ & 0 & 0 & Fish \\
\hline Bering skate & 34 & $40-79$ & 0 & 0 & Euphausid shrimp, crab \\
\hline Aleutian skate & 24 & $27-158$ & 0 & 0 & Shrimp, pollock, crab \\
\hline Whitebrow skate & 12 & $77-82$ & 0 & 0 & Shrimp \\
\hline Mud skate & 123 & $44-76$ & 0 & 0 & Euphausid shrimp \\
\hline \multicolumn{6}{|l|}{ Bering skate-Pervenets Canyon (BR-PN) } \\
\hline Pacific cod & 6 & $53-83$ & 1 & 2 & Fish, shrimp, crab \\
\hline Pacific halibut & 9 & $77-96$ & 0 & 0 & Pollock, cephalopod \\
\hline Bigmouth sculpin & 9 & $56-69$ & 0 & 0 & Fish \\
\hline Greenland turbot & 16 & $50-100$ & 0 & 0 & Squid \\
\hline Bering skate & 22 & $23-80$ & 0 & 0 & Gammarid, shrimp \\
\hline Alaska skate & 16 & $74-112$ & 0 & 0 & Pollock \\
\hline Aleutian skate & 33 & $40-140$ & 0 & 0 & Pollock, euphausid \\
\hline Whitebrow skate & 13 & $62-79$ & 0 & 0 & Shrimp \\
\hline Mud skate & 51 & $35-69$ & 0 & 0 & Gammarid, polychaete, crab \\
\hline Whiteblotched skate & 22 & $55-107$ & 1 & 2 & Pollock, shrimp, cephalopod \\
\hline \multicolumn{6}{|l|}{ Bering skate-Bristol Canyon (BR-BL) } \\
\hline Arrowtooth flounder & 85 & $31-87$ & 0 & 0 & Pollock, cephalopod \\
\hline Pacific cod & 66 & $38-87$ & 0 & 0 & Pollock, crab \\
\hline Pacific halibut & 6 & $59-115$ & 0 & 0 & Pollock \\
\hline Bigmouth sculpin & 1 & 59 & 0 & 0 & Fish \\
\hline Greenland turbot & 2 & $89-90$ & 0 & 0 & - \\
\hline Bering skate & 15 & $40-75$ & 0 & 0 & Crab, fish, shrimp \\
\hline Alaska skate & 19 & $28-114$ & 0 & 0 & Pollock, amphipod \\
\hline Aleutian skate & 4 & $86-155$ & 0 & 0 & Pollock, crab \\
\hline
\end{tabular}




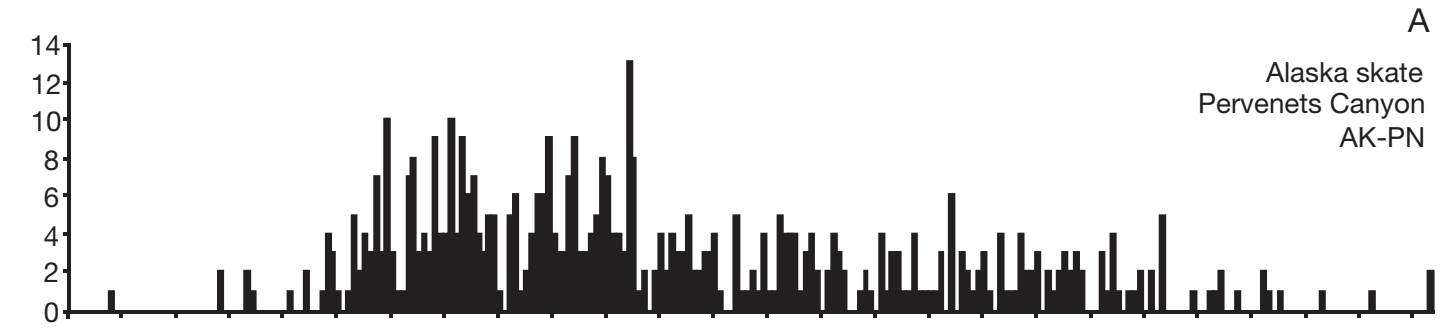

B
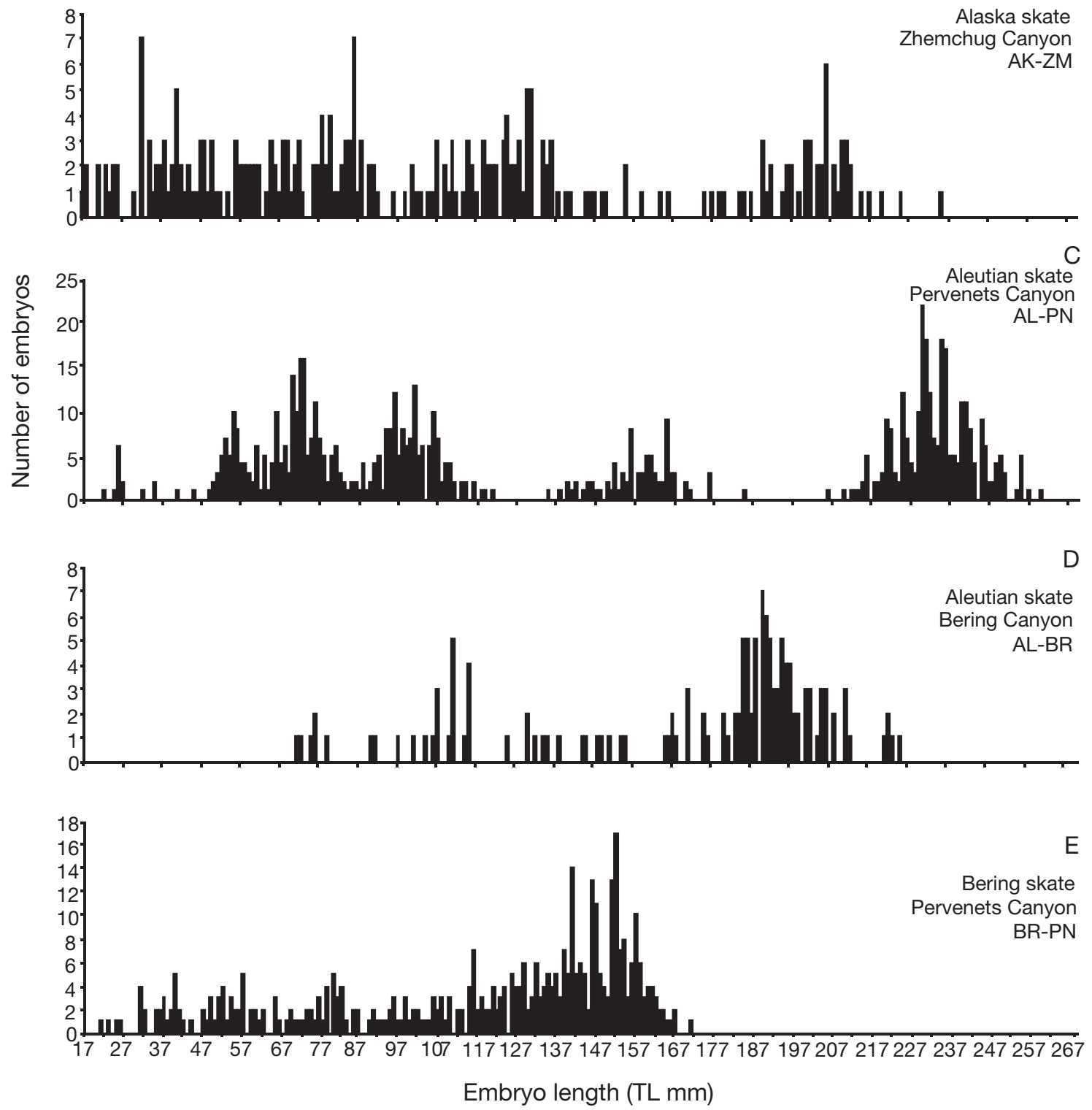

Fig. 4. Length composition by skate species of developing embryos from random samples at each nursery site indicated (see Table 1 for nursery site designations). Stage 1 eggs (not shown) are newly deposited eggs and show little embryo development or possessed embryos that were too small for measurements. The histogram represents the number of embryos developed further enough to be available for measurement. (A) stage $1 \mathrm{n}=134$, embryo $\mathrm{n}=489$; (B) stage $1 \mathrm{n}=97$, embryo $\mathrm{n}=265$; (C) stage $1 \mathrm{n}=$ 101, embryo $n=707$; (D) stage $1 \mathrm{n}=3$, embryo $\mathrm{n}=140$; $(\mathrm{E})$ stage $1 \mathrm{n}=119$, embryo $\mathrm{n}=404$. Eggs from nursery sites $A, B$ and $E$ were collected in August and C and D came from October sampling. TL: total length 


$$
\frac{1+14}{(3)}
$$




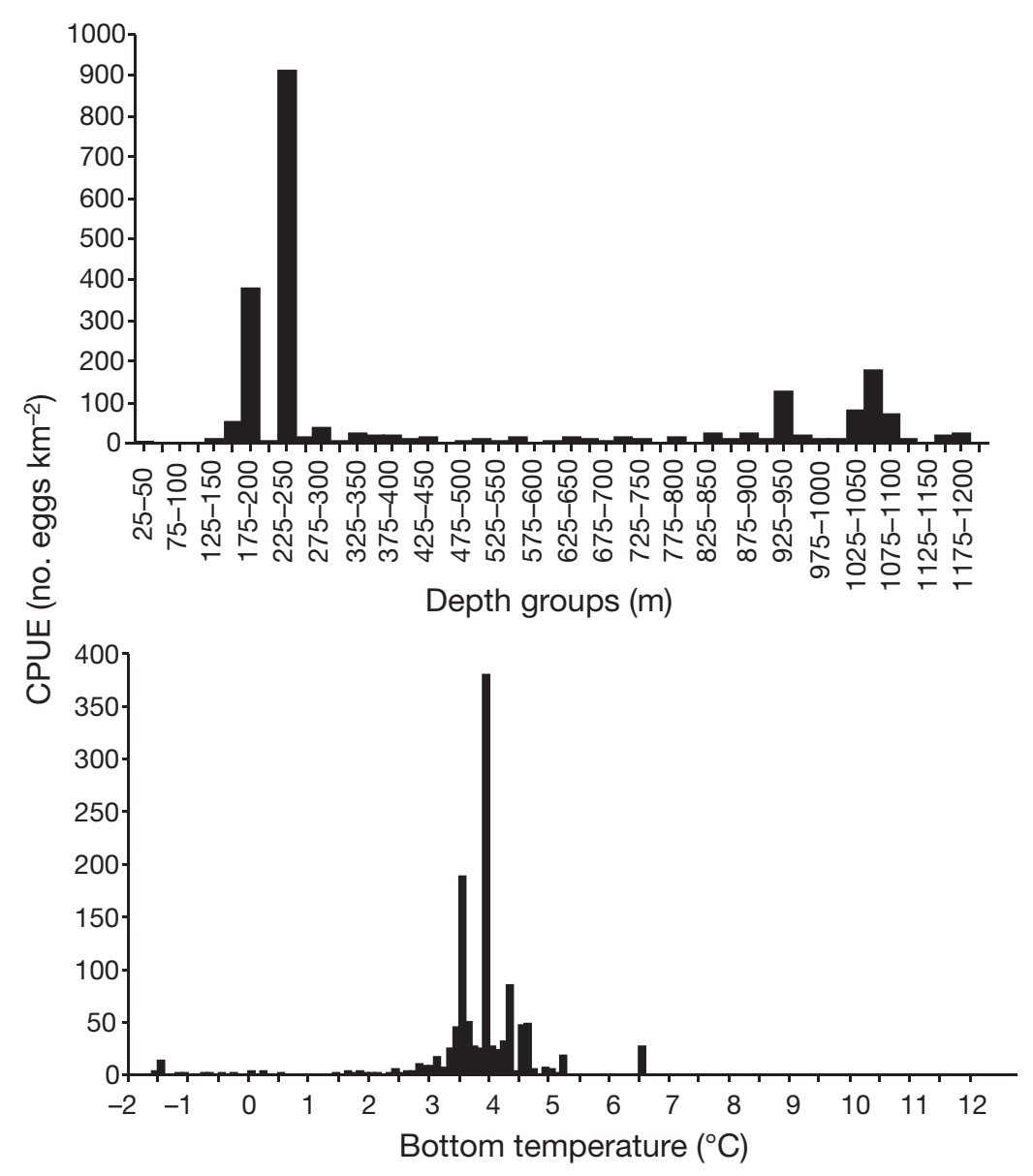

Fig. 6. Mean catch abundance in the eastern Bering Sea of skate egg cases by depth group ( $25 \mathrm{~m}$ interval, top panel) and by bottom temperature (bottom panel) from the Alaska Fisheries Science Center's standard bottom trawl surveys for years 1982 to 2009. CPUE: catch per unit effort

(Stabeno et al. 1999), nutrients (Whitledge \& Luchin 1999), sediment types (Karl \& Carlson 1987) and temperature regimes (Luchin et al. 1999). These areas possess physical features that may produce optimal conditions for the long development time required by embryos in sub-arctic waters (Hoff 2007, 2008, 2009a). EBS canyons can be highly productive with northerly slope currents causing upwelling and high primary production (Springer \& McRoy 1996, Stabeno et al. 1999), which in turn can support high biomass of birds (Piatt et al. 2006), mammals (Loughlin et al. 1999) and fish and invertebrate species (Brodeur 2001, Stevenson et al. 2008). Nursery sites located in highly productive areas can provide ample prey for reproductively active skates. Diets of mature skates at nursery sites suggest feeding occurs during reproductive periods and throughout the year (Hoff 2008). Readily available food during protracted egg laying periods would lessen the need for energy expenditures and forays for food outside nursery habitat. The abundant prey also may explain the high biomass and diversity of skate species and the presence of other large predatory fish species such as Pacific cod, Pacific halibut and arrowtooth flounder Atheresthes stomias found at nursery sites.

Skate embryo development time is correlated with water temperature (Berestovskii 1994, Hoff 2007, 2008, unpubl. data) and shorter development times may increase recruitment potential through decreased exposure to predation (Hoff 2007, 2008, 2009b) and greater hatching success. The upper slope environment has relatively warm and stable average annual bottom temperatures when compared with the whole EBS. Seasonal sampling from the Alaska skate and Aleutian skate sites (AK-BR, AL-BR) in the southern EBS show water temperatures varying by only $0.5^{\circ} \mathrm{C}$ annually (Table 1). Shallower shelf waters in most winters are ice-covered in the central EBS and bottom water temperatures reach $<1^{\circ} \mathrm{C}$ for many months of the year (Niebauer et al. 1999). Survey data indicates skate nursery sites may be concentrated at depths and temperatures similar to those that exist on the outer continental shelf and upper slope of the EBS.

Bottom structure, identified from species composition, gear performance and echosounder data, at nursery sites showed relatively flat sandy bottoms with no vertical structure or hard (rocky) substrates. Nursery sites in rocky reefs and high energy flow areas like that recently reported from Monterey Canyon (Love et al. 2008) and those in the Aleutian Islands (unpubl. data) suggest skate eggs may require attachment to benthic structures such as rocks and sponges to prevent them from being dispersed from optimal habitat. EBS skates may not require attachment structure as the EBS slope currents are slower than those of rocky reef nursery sites in Aleutian Island passes (Reed \& Stabeno 1999). Moderate currents such as those along the upper slope of the EBS may create sufficient water flow across the egg surface to sustain metabolic processes (Hoff 2007, 2008, Leonard et al. 1999) and ensure eggs are not covered with sediments, yet moderate enough not to scatter eggs up onto the shelf or into deeper waters to suboptimal habitat.

Skate nursery sites in the EBS show evidence of continous use throughout the year as well as a persistence through time. Fisheries data from bottom trawling in 
this region indicate North Pacific fisheries observers have reported large catches of skate egg cases from the AK-BR site for $>20 \mathrm{yr}$ and other locations for at least 10 yr (North Pacific Fisheries Groundfish Observer Program unpubl. data).

Generalized lifetime movement patterns and nursery site use for EBS skates suggest unique habitat requirements for each life stage of embryo, juvenile, immature and mature skates (Fig. 7). Although the upper slope environment may be optimal as nursery habitat during embryo development, it appears not to be for neonates and juvenile skates. Neonates of slopedwelling skate species migrated to deeper slope waters and returned to shallower depths with increased size, reaching the upper shelf-slope interface at mature sizes. The Alaska skate is primarily a shelf species and movement patterns showed this species used the depths of the inner and middle shelf of the EBS for immature sizes (Hoff 2007, 2008) and returned to the outer shelf depths at mature sizes (Matta \& Gunderson 2007) where the juveniles and nursery sites occurred. The dramatic shift from nursery site depths for neonates and juveniles to deeper or much shallower water may be directly linked to predator avoidance. Juvenile skates that use the lower slope habitat after emergence may avoid predation as the large predatory fish species prevalent at lower slope depths, such as the giant grenadier Albatrossia pectoralis, the arrowtooth flounder Atheresthes stomias and the Greenland turbot Reinhardtius hippoglossoides have not been shown to prey on juvenile skates (AFSC
Feeding Ecology Lab unpubl. data). The predators of neonate skates, Pacific cod and Pacific halibut, rarely occur below $600 \mathrm{~m}$ along the eastern Bering Sea slope (Hoff \& Britt 2009) and are smaller in the middle and inner shelf than in the outer shelf and upper slope (Lauth \& Acuna 2009) where nursery sites occur. Predator avoidance by newly emergent neonates may allow for high recruitment potential by separation of predator and prey during early life stages.

Skate nursery site location and surrounding physical oceanographic characteristics, coupled with skate behavior, may be critical elements for successful skate reproduction. Patterns relating to the general distribution and habitat requirements for skates are emerging from this study. The unique physical relationship between skate nursery site placement and canyon habitat remains to be studied in detail. However, highly productive canyon areas are often heavily fished with bottom trawl and longline, which increases the vulnerability of the most critical life stages of skates (reproductive adults and developing embryos) as there is a direct overlap of zones of high fishing effort and skate nursery habitat. Identification and characterization of these fragile habitats are the important first steps in developing management and conservation strategies for these vulnerable species.
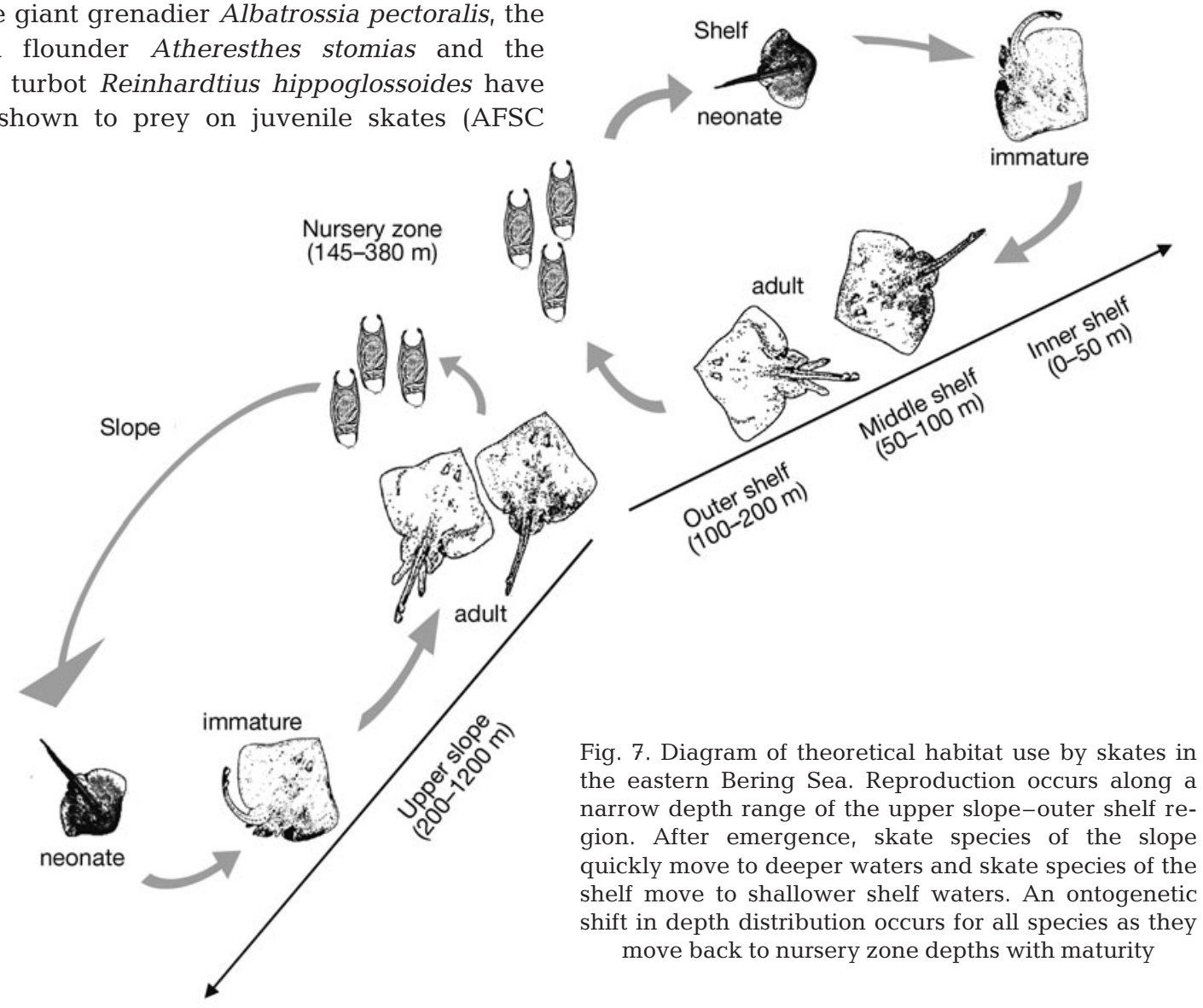
Acknowledgements. I thank the skippers and crew of the FVs 'Ocean Explorer', 'Sea Storm', 'Nordic Fury', 'Arcturus', 'Aldebaran', 'Great Pacific', 'Northwest Explorer', 'Vesteraalen' and NOAA ship RV 'Miller Freeman'. I especially thank D. Stevenson and S. Kotwicki for their help with field studies and G. Stauffer, R. Nelson and B. Lauth for their support over the years. Thanks to D. Stevenson, J. Boldt, B. Lauth, D. Somerton, R. Nelson, J. Lee, G. Duker and unidentified reviewers for their helpful comments and suggestions to improve this manuscript. This project was supported by the North Pacific Research Board (NPRB grant no. 415), Essential Fish Habitat (EFH) funding and generous support from the Alaska Fisheries Science Center.

\section{LITERATURE CITED}

Berestovskii EG (1994) Reproductive biology of the family Rajidae in the seas of the far north. J Ichthyol 34:26-37

Brodeur RD (2001) Habitat-specific distribution of Pacific ocean perch (Sebastes alutus) in Pribilof Canyon, Bering Sea. Cont Shelf Res 21:207-224

Carlson JK (1999) Occurrence of neonate and juvenile sandbar sharks, Carcharhinus plumbeus, in the northeastern Gulf of Mexico. Fish Bull 97:387-391

Carlson PR, Karl HA (1988) Development of large submarine canyons in the Bering Sea, indicated by morphological, seismic, and sedimentologic characteristics. Geol Soc Am Bull 100:1594-1615

Castro JI (1993) The shark nursery of Bulls Bay, South Carolina, with a review of the shark nurseries of the southeastern coast of the United States. Environ Biol Fishes $38: 37-48$

Feldheim KA, Gruber SH, Ashley MV (2002) The breeding biology of lemon sharks at a tropical nursery lagoon. Proc Biol Sci 269:1655-1661

Hitz CR (1964) Observations on egg cases of the big skate (Raja binoculata Girard) found in Oregon coastal waters. J Fish Res Board Can 21:851-854

Hoff GR (2007) Reproductive biology of the Alaska skate Bathyraja parmifera, with regard to nursery sites, embryo development and predation. PhD dissertation, University of Washington, Seattle, WA

Hoff GR (2008) A nursery site of the Alaska skate (Bathyraja parmifera) in the eastern Bering Sea. Fish Bull 106: 233-244

Hoff GR (2009a) Embryo developmental events and the egg case of the Aleutian skate Bathyraja aleutica (Gilbert) and the Alaska skate Bathyraja parmifera (Bean). J Fish Biol 74:483-501

Hoff GR (2009b) Skate Bathyraja spp. egg predation in the eastern Bering Sea. J Fish Biol 74:250-269

Hoff GR, Britt LL (2003) The 2002 eastern Bering Sea upper continental slope survey of groundfish and invertebrate resources. NOAA Tech Memo NMFS-AFSC-141

Hoff GR, Britt LL (2005) Results of the 2004 eastern Bering Sea upper continental slope survey of groundfish and invertebrate resources. NOAA Tech Memo NMFS-AFSC156

Hoff GR, Britt LL (2009) Results of the 2008 eastern Bering Sea upper continental slope survey of groundfish and invertebrate resources. NOAA Tech Memo NMFS-AFSC197

Karl HA, Carlson PR (1987) Surface current patterns suggested by suspended sediment distribution over the outer continental margin, Bering Sea. Mar Geol 74:301-308
Lauth RR, Acuna E (2009) Results of the 2008 eastern Bering Sea continental shelf bottom trawl survey of groundfish and invertebrates resources. NOAA Tech Memo NMFSAFSC-195

Leonard JBK, Summers AP, Koob TJ (1999) Metabolic rate of embryonic little skate, Raja erinacea (Chondrichthyes: Batoidea): the cost of active pumping. J Exp Zool 283: 13-18

Loughlin TR, Sukhanova IN, Sinclair EH, Ferrero RC (1999) Summary of biology and ecosystem dynamics in the Bering Sea. In: Loughlin TR, Ohtani K (eds) Dynamics of the Bering Sea. University of Alaska Sea Grant College Program, AK-SG-99-03, Fairbanks, AK, p 386-407

Love MS, Schroeder DM, Snook L, York A, Cochrane G (2008) All their eggs in one basket: a rocky reef nursery for the longnose skate (Raja rhina Jordan \& Gilbert, 1880) in the southern California Bight. Fish Bull 106:471-475

Luchin VA, Menovshchikov VA, Lavrentiev VM, Reed RK (1999) Thermohaline structure and water masses in the Bering Sea. In: Loughlin TR, Ohtani K (eds) Dynamics of the Bering Sea. University of Alaska Sea Grant College Program, AK-SG-99-03, Fairbanks, AK, p 61-91

> Matta ME, Gunderson DR (2007) Age, growth, maturity, and mortality of the Alaska skate, Bathyraja parmifera, in the eastern Bering Sea. Environ Biol Fishes 80:309-323

Niebauer HJ, Bond NA, Yakunin LP, Plotnikov VV (1999) An update on the climatology and sea ice of the Bering Sea. In: Loughlin TR, Ohtani K (eds) Dynamics of the Bering Sea. University of Alaska Sea Grant, AK-SG-99-03, Fairbanks, AK, p 29-60

Packer DB, Christine AZ, Vitaliano JJ (2003) Barndoor skate, Dipturus laevis, life history and habitat characteristics. NOAA Tech Memo NMFS-NE-173

Piatt JF, Wetzel J, Bell K, DeGange AR and others (2006) Predictable hotspots and foraging habitat of the endangered short-tailed albatross (Phoebastrina albatrus) in the North Pacific: implications for conservation. Deep-Sea Res II 53:387-398

Reed RK, Stabeno PJ (1999) The Aleutian North Slope Current. In: Loughlin TR, Ohtani K (eds) Dynamics of the Bering Sea. University of Alaska Sea Grant College Program, AK-SG-99-03, Fairbanks, AK, p 177-191

Springer AM, McRoy CP (1996) The Bering Sea greenbelt: shelf edge processes and ecosystem production. Fish Oceanogr 5:205-223

Stabeno PJ, Schumacher JD, Ohtani K (1999) The physical oceanography of the Bering Sea. In: Loughlin TR, Ohtani $\mathrm{K}$ (eds) Dynamics of the Bering Sea. University of Alaska Sea Grant College Program, AK-SG-99-03, Fairbanks, AK, p 1-28

Stauffer G (2004) NOAA protocols for groundfish bottom trawl surveys of the nation's fishery resources. NOAA Tech Memo NMFS-F/SPO-65

Stevenson DE (2004) Identification of skates, sculpins, and smelts by observers in North Pacific groundfish fisheries (2002-2003). NOAA Tech Memo NMFS-AFSC-142

Stevenson DE, Orr JW, Hoff GR, McEachran JD (2008) Emerging patterns of species richness and density in the skates (Rajidae) of Alaska. Fish Bull 106:24-39

Whitledge TE, Luchin VA (1999) Summary of chemical distributions and dynamics in the Bering Sea. In: Loughlin TR, Ohtani K (eds) Dynamics of the Bering Sea. University of Alaska Sea Grant College Program, AK-SG-99-03, Fairbanks, AK, p 217-250

Yokota L, Lessa RP (2006) A nursery area for sharks and rays in Northeastern Brazil. Environ Biol Fishes 75:349-360 